\title{
PAŽEIDŽIAMŲ ASMENŲ DALYVAVIMO IR PSICHIKOS LIGONIŲ SUTIKIMO DALYVAUTI KLINIKINIUOSE VAISTINIŲ PREPARATŲ TYRIMUOSE TEISINIO REGULIAVIMO PROBLEMOS LIETUVOJE
}

\author{
Kristina Zamarytè-Sakavičienè \\ Mykolo Romerio universiteto Teisès fakulteto \\ Teisès filosofijos ir istorijos katedra \\ Ateities g. 20, LT-08303 Vilnius, Lietuva \\ Telefonas (+370 5) 2714576 \\ Elektroninis paštas slepyne@yahoo.com
}

Pateikta 2013 m. spalio 20 d., parengta spausdinti 2013 m. gruodžio 20 d.

doi:10.13165/SPV-14-1-6-12

\section{Santrauka}

Pagal galimos ịtakos sutikimui dalyvauti biomedicininiuose tyrimuose pobūdị yra skiriamos pažeidžiamų asmenu grupès. Kai kurie Biomedicininiu tyrimu etikos įstatyme ir kituose Lietuvos Respublikos teises aktuose nustatyti klinikiniu vaistiniu preparatu tyrimy su pažeidžiamais asmenimis reikalavimai yra büdingi tik Lietuvos nacionalinei teisei ir tam tikrais atvejais gali būti vertinami kaip pertekliniai, ribojantys tyrimu su pažeidžiamais asmenimis atlikima bei ju kontrole Lietuvoje. Straipsnyje nagrinejjamos bendros pažeidžiamu asmenu apsaugos garantijos ir pateikiama psichikos ligoniu dalyvavimo tyrimuose (psichikos ligoniu sutikimui taikomi reikalavimai, psichikos ligoniu kompetencija duoti sutikima, sutikime dalyvaujantys asmenys) teisinio reguliavimo analize.

Reikšminiai žodžiai: klinikiniai tyrimai, biomedicininiai tyrimai, vaistiniai preparatai, pažeidžiami asmenys, psichikos ligoniai.

\section{Ivadas}

Teisès normų, reguliuojančių klinikinių vaistinių preparatų tyrimų (KVPT, tyrimai) vykdymą, paskirtis yra užtikrinti, kad: 1) KVPT metu surinkta mokslinė informacija apie vaistą būtų kokybiška (tiksli, visapusiška, patikima), t. y. tinkama vaistinio preparato savybėms vertinti; 2) KVPT dalyvaujančių tiriamųjų asmenų gerovè, teisès ir interesai būtų apsaugoti. Europos Sąjungoje imtasi priemonių suvienodinti teisinius KVPT vykdymo 
reikalavimus - priimtos Europos Sąjungos direktyvos 2001/20/EB ${ }^{1}$ ir 2005/28/EB ${ }^{2}$ bei jomis nustatyta, kad visus KVPT privaloma vykdyti, laikantis geros klinikinès praktikos (GKP) nuostatų. Nacionaliniai teisès aktai, iggvendinantys minètas direktyvas, reglamentuoja KVPT atlikimo, kontrolès, liudijimų ir leidimų atlikti KTVP išdavimo tvarką bei atvejus, kai liudijimas ar leidimas neišduodamas ${ }^{3,4,5}$.

Atsižvelgiant ì skirtingų populiacijų ypatumus, biomedicininiuose tyrimuose yra išskiriamos pažeidžiamų asmenų grupès. Biomedicininių tyrimų etikos ịstatymas (BTEIt) pažeidžiamus asmenis apibrežia kaip asmenis, kurių sutikimui dalyvauti biomedicininiame tyrime gali turèti įtakos išorinès aplinkybès, išvardina pažeidžiamų asmenų grupes bei nustato jų apsaugos garantijas. Kai kurie tyrimų su pažeidžiamais asmenimis reikalavimai, nustatyti BTEI ir kituose įstatymuose, yra būdingi tik Lietuvos nacionalinei teisei ir tam tikrais atvejais gali būti vertinami kaip pertekliniai bei ribojantys KVPT atlikimą Lietuvoje.

Šio straipsnio tikslas - išnagrinèti nacionalinių teisès aktų nuostatų, reglamentuojančiu pažeidžiamų asmenų dalyvavimą KVPT, savitumus. BTEĮ be bendrųjų pažeidžiamų asmenų apsaugos garantijų, nustato specialius reikalavimus nepilnamečių ir psichikos sutrikimus turinčių asmenų sutikimui dalyvauti tyrime. Vaikų dalyvavimo KVPT teisinio reguliavimo Lietuvoje problematiką išsamiai nagrinejjo J. Juškevičius ${ }^{6}$, D. Stakišaitis ${ }^{7}$ ir K. ZamarytėSakvičiene $\dot{e}^{8}$, todèl šiame straipsnyje apsiribojama bendrų pažeidžiamų asmenų apsaugos garantijų ir psichikos ligonių sutikimo dalyvauti KVPT teisinio reguliavimo analize.

Pasirinktos straipsnio problematikos aktualumą patvirtina tai, kad po GKP inspekcijos metu nustatytų pavojingų (kritinių) pažeidimų Lietuvoje vykusiame psichiatriniame tyrime Lietuvos Respublikos Seimo kontrolierius $2013 \mathrm{~m}$. kovo 19 d. rekomendavo Valstybinès vaistų kontrolès tarnybos (VVKT) viršininkui apsvarstyti galimybę per metus tikrinti bent vieną iš psichiatrinių KVPT $\mathrm{K}^{9}$. Teisinio reguliavimo spragos, ịstatymų igyvendinamųjų aktų reguliavimo stoka ir perteklinès pažeidžiamų asmenų apsaugos garantijos apsunkina ne tik psichiatrinių tyrimų vykdymą, bet ir leidimų atlikti šiuos tyrimus išdavimą bei jų kontrolę Lietuvoje.

12001 m. balandžio 4 d. Europos Parlamento ir Tarybos direktyvoje 2001/20/EB dèl valstybių narių ịstatymų ir kitų teisės aktų, susijusių su geros klinikinès praktikos igyvendinimu atliekant žmonèms skirtų vaistų klinikinius tyrimus, suderinimo. [2001] OL L 121/34.

$22005 \mathrm{~m}$. balandžio 8 d. Komisijos direktyvos 2005/28/EB, nustatančios geros klinikinès praktikos, susijusios su tiriamaisiais žmonèms skirtais vaistais, principus bei išsamias gaires ir leidimui gaminti ir importuoti tokius vaistus keliamus reikalavimus. [2005] OL L91/13.

3 Pritarimo atlikti klinikinị vaistinio preparato tyrimą liudijimų ir leidimų atlikti klinikinị vaistinio preparato tyrimą išdavimo, tyrimų atlikimo ir kontrolès tvarkos aprašas, patvirtintas Lietuvos Respublikos sveikatos apsaugos ministro $2006 \mathrm{~m}$. gegužès $31 \mathrm{~d}$. ịsakymu Nr. V-435, su pakeitimais. Valstybès žinios. 2006, Nr. 62-2292; 2010, Nr. 108-5566; 2011, Nr. 33-1569; 2011, Nr. 96-4524.

4 Lietuvos Respublikos farmacijos ịstatymas. Valstybès žinios. 2006, Nr. 78-3056.

5 Lietuvos Respublikos biomedicininių tyrimų etikos ịstatymas. Valstybés žinios. 2000, Nr. 44-1247.

${ }_{6}$ Juškevičius, J. Kai kurie nepilnamečiu ịtraukimo ị klinikinius vaistinių preparatų tyrimus teisiniai aspektai. Sveikatos mokslai. 2009, 6(66): 27-34.

7 Stakišaitis, D. Vaikų gydymo vaistais teisinio reglamentavimo aspektai. Jurisprudencija. 2008, 12(114): 36-43.

8 Zamarytė-Sakavičienè, K. Asmens sutikimo dalyvauti pediatriniame klinikiniame vaistinio preparato tyrime teisiniai aspektai. Socialiniu mokslu studijos. 2013, 5(1): 275-290.

9 Pažyma dèl Seimo kontrolieriaus iniciatyva pradèto tyrimo prieš Valstybinę vaistų kontrolès tarnybą prie Lietuvos Respublikos sveikatos apsaugos ministerijos. Seimo kontrolierių ỉstaiga [interaktyvus]. Vilnius, 2013, Nr. 4D-2012/1-1418 [žiūrèta 2013-04-18]. <http://www.lrski.lt/index_neig. php? $=0 \& n=62 \& l=1 t \& s e a r c h=0 \& g r=\& p a z y m a=7021>$. 
Šio straipsnio objektas yra Europos Tarybos, Europos Sąjungos ir Lietuvos Respublikos teisès aktų nuostatos, reglamentuojančios svarbiausius pažeidžiamų asmenų dalyvavimo KVPT aspektus (pažeidžiamų asmenų sąvoka, grupės, bendrieji apsaugos reikalavimai, psichikos ligonių sutikimui taikomi reikalavimai, psichikos ligonių kompetencija duoti sutikimą).

Straipsniu siekiama: 1) ịvertinti, ar Lietuvoje teisès normomis nustatant pažeidžiamų asmenų dalyvavimo KVPT tvarką nėra sudaromos nepagrịstos kliūtys atlikti KVPT su pažeidžiamais asmenimis; 2) išanalizuoti psichikos ligonio sutikimo dalyvauti KVPT teisinio reglamentavimo problemas; 3) pateikti pasiūlymus nustaty toms problemoms spręsti.

Rašant straipsnị taikyti literatūros šaltinių, dokumentų analizès, sisteminès analizès, lyginamasis, sintezès ir apibendrinimo metodai.

\section{Bendrieji pažeidžiamų asmenų apsaugos reikalavimai}

\subsection{Pažeidžiamų asmenų sąvoka ir grupès}

Atsižvelgiant i skirtingų populiacijų ypatumus, klinikiniuose tyrimuose yra skiriamos pažeidžiamų asmenų grupès - tai asmenys, kurių kompetencija (gebejjimas, galèjimas) duoti sutikimą dalyvauti tyrime dèl tam tikrų priežasčių yra kvestionuotina ${ }^{10}$. BTEI 5 str. $1 \mathrm{~d}$. pažeidžiamus asmenis apibrěžia kaip asmenis, kurių sutikimui dalyvauti biomedicininiame tyrime gali turèti ịtakos išorines aplinkybès. İstatymas išvardina 6 pažeidžiamų asmenų grupes (asmenys, turintys psichikos sutrikimų, bet galintys duoti sutikimą dalyvauti biomedicininiame tyrime; nepilnamečiai; studentai, jei jų dalyvavimas biomedicininiame tyrime susijęs su studijomis; asmenys, gyvenantys globos ịstaigose; kariai jų tikrosios karinės tarnybos metu; sveikatos priežiūros ịstaigų, kuriose atliekamas biomedicininis tyrimas, darbuotojai, pavaldūs tyrejjui) ir imperatyviai nurodo, kad biomedicininiai tyrimai negali būti atliekami su ịkalinimo ìstaigose ar kitose laisvès atėmimo vietose esančiais asmenimis. GKP taisyklių 1.61 p. BTEI pateiktą pažeidžiamų asmenų apibrèžimą detalizuoja, nurodydamas aplinkybes, kurios gali turèti pernelyg didelès ịtakos PA sutikimui savanoriškai dalyvauti klinikiniame tyrime, t. y. „kokios nors naudos lūkesčiai arba aukštesniųjų pareigūnų keršto baimè, atsisakius dalyvauti tyrime" ${ }^{\text {"11 }}$. Pagal galimos ịtakos savanoriškam sutikimui pobūdi GKP taisyklès pateikia du pažeidžiamų asmenų grupių sąrašus ${ }^{12}$. BTEI nustatytas pažeidžiamų asmenų sąrašas yra siauresnis nei GKP taisyklèse. Ministro ísakymu patvirtintomis GKP taisyklemis nustatytas teisinis reguliavimas negali prieštarauti įstatymui, tačiau BTEI 5 str. 3 d. nurodo, kad Lietuvos bioetikos komitetas motyvuotu sprendimu gali pripažinti (priskirti) ir kitų (ne tik išvardintų BTEI 5 str. 1 d.) asmenų grupes pažeidžiamais asmenimis. Tokio Lietuvos bioetikos komiteto sprendimo motyvai galètų būti paremti GKP taisyklèse nustatytais galimos ịtakos savanoriškam sutikimui kriterijais („naudos lūkesčiai arba aukštesniųjų pareigūnų keršto baimė“) ir GKP taisyklių 1.61 p. pateiktais pažeidžiamų asmenų grupių sąrašais.

10 Miracle, V. Vulnerable Populations in Research. Dimensions Of Critical Care Nursing. 2010, 29(5): 242-245.

11 Lietuvos Respublikos sveikatos apsaugos ministro 1998 m. birželio 12 d. ịsakymu Nr. 320 patvirtintos Geros klinikinès praktikos taisyklès. Valstybès žinios. 1998, Nr. 57-1608.

12 Hierarchinès grupés nariai medicinos, farmacijos, stomatologijos ir slaugos studentai, pavaldus ligoninès bei laboratorijos personalas, farmacijos pramonés darbuotojai, karinių pajègų nariai ir asmenys, laikomi ịkalinimo įstaigose; pacientai, sergantys nepagydomomis ligomis, arba tokie, kurių būklè kritiška, asmenys, gyvenantys slaugos ịstaigose, bedarbiai arba vargšai, etninių mažumų grupès, benamiai, klajokliai, pabègèliai, nepilnamečiai, taip pat ir asmenys, kurie patys nepajègūs duoti sutikimą. 
Svarbu pažymèti, kad minètuose teisès aktuose pateikiama pažeidžiamų asmenų grupių klasifikacija skiriasi nuo pažeidžiamų asmenų grupių, kurios yra nurodytos Europos Komisijos $^{13}$ ir Valstybinès vaistų kontrolès tarnybos viršininko įsakymu ${ }^{14}$ patvirtintos leidimui atlikti KVPT gauti paraiškos formos F.3.3 dalyje:

1 lentelè. KVPT paraiškos formos F3 dalis

\begin{tabular}{|l|c|c|}
\hline F.3 Tiriamųjų grupės & Taip & $\mathrm{Ne}$ \\
\hline F.3.1 Sveiki savanoriai & $\mathrm{o}$ & $\mathrm{o}$ \\
\hline F.3.2 Pacientai & $\mathrm{o}$ & $\mathrm{o}$ \\
\hline F.3.3 Specifinės pažeidžiamos grupės: & $\mathrm{o}$ & $\mathrm{o}$ \\
\hline F.3.3.1 Vaisingo amžiaus moterys & $\mathrm{o}$ & $\mathrm{o}$ \\
\hline F.3.3.2 Vaisingo amžiaus moterys, naudojančios kontracepciją & $\mathrm{o}$ & $\mathrm{o}$ \\
\hline F.3.3.3 Něščiosios & $\mathrm{o}$ & $\mathrm{o}$ \\
\hline F.3.3.4 Žindyvès & $\mathrm{o}$ & $\mathrm{o}$ \\
\hline F.3.3.5 Pacientai, kuriems būtina neatidèliotina pagalba & $\mathrm{o}$ & $\mathrm{o}$ \\
\hline $\begin{array}{l}\text { F.3.3.6 Asmenys, negalintys duoti sutikimo: } \\
\text { F.3.3.6.1 Jei taip, patikslinkite: }\end{array}$ & $\mathrm{o}$ & $\mathrm{o}$ \\
\hline $\begin{array}{l}\text { F.3.3.7 Kita: } \\
\text { F.3.3.7.1 Jei taip, patikslinkite: }\end{array}$ & $\mathrm{o}$ & $\mathrm{o}$ \\
\hline
\end{tabular}

Taigi trijuose Lietuvos teisès aktuose nurodomos pažeidžiamų asmenų grupès skiriasi. BTEI ir GKP taisyklèse pateikiami pažeidžiamų asmenų sąrašai nesutampa, be to, jie neapima visų leidimui atlikti KVPT gauti paraiškoje nurodytų specifinių pažeidžiamųjų asmenų grupių (vaisingo amžiaus moterų, nėščiųjų, žindyvių).

\subsection{Vaisingo amžiaus, néščių ir žindančių moterų priskyrimo pažeidžiamų asmenų grupei svarba}

Siekdami išvengti teisinès atsakomybės už galimą žalą něščiai moteriai, vaisiui (embrionui) ar žindomam kūdikiui, KVPT užsakovai vengia atlikti tyrimus su nėščiosiomis, žindančiomis, vaisingo amžiaus moterimis, jų apsaugos tikslu atitinkamai suformuluoja ịtraukimo ir neịtraukimo ị tyrimą kriterijus ${ }^{15}$. Tačiau šios asmenų grupés taip pat susiduria su ịvairiais sveikatos sutrikimais, kuriems reikalingas medikamentinis gydymas. Nesant pakankamų KVPT duomenų apie vaisto saugumą ir veiksmingumą, pvz., něščiųų populiacijoje, gydymo

13 Europos Komisijos 2010 m. kovo 30 d. išsamios gairès 2010/C 82/01 dèl prašymų gauti kompetentingos institucijos leidimą atlikti žmonėms skirto vaistinio preparato klinikinius tyrimus, esminių pataisų ir deklaracijos apie klinikinio tyrimo pabaigą pateikimo (CT-1). [2010] OL C82/1.

14 Paraiškos leidimui atlikti žmonems skirtų vaistinių preparatų klinikinị tyrimą gauti, pranešimo apie esmines pataisas ir tyrimo pabaigos deklaracijos pateikimo tvarkos aprašas, patvirtintas Valstybinès vaistų kontrolès tarnybos prie Lietuvos Respublikos sveikatos apsaugos ministerijos viršininko $2006 \mathrm{~m}$. liepos 14 d. įsakymu Nr. 1A-396. Valstybès žinios. 2006, Nr. 81-3241.

15 Merton, V. The Exclusion of Pregnant, Pregnable, and Once-Pregnable People (a.k.a. Women) from Biomedical Research. American Journal Of Law \& Medicine.1993, 19(4): 369. 
metu kyla rizika vaisiaus (embriono, gimsiančio vaiko) ir nėščios moters sveikatai ${ }^{16}$. Todèl tokie klinikiniai tyrimai yra būtini pačių něščųjų ir gimsiančių vaikų labui.

Oviedo konvencijos ${ }^{17} 18$ str. ir BTEI 3 str. 2 d. embrionui ${ }^{18}$ ir vaisiui ${ }^{19}$ nustato tam tikrą apsaugą biomedicininių tyrimų srityje. Kai kurių autorių nuomone, klinikiniame tyrime, kuriame dalyvauja néščia moteris, tiek ji pati, tiek jos vaisius yra laikytini pacientais (tiriamaisiais asmenimis) ${ }^{20,21}$. Tačiau Lietuvoje civilinio teisnumo (galejjimo turèti civilines teises ir pareigas) atsiradimas siejamas su gimimu (CK 2.2 str. 1 d.). Tai reiškia, kad vaisius (embrionas) nèra laikomas teisių subjektu, kurio vardu sutikimą dalyvauti tyrime turètų duoti jo atstovai. Vaikas per savo atstovus dalyvautų sutikimo procese, kuriam reikalavimus nustato BTEI ir kiti teisès aktai, tik nuo gimimo momento. Ittraukiant nèščią moterị i KVPT, pagal BTEI užtektų jos vienos, kaip tiriamojo asmens, sutikimo - ị vaiko tèvo valią tyrèjas neprivalètų atsižvelgti. Pabrěžtina, kad BTEI 3 str. 1 d. pats vaisius (ne nėščia moteris) gali būti biomedicinių tyrimų objektu. Taip pat Lietuvoje su embrionu leidžiama atlikti klinikinius stebejimus (neinvazinius tyrimus), o su vaisiumi - biomedicininius tyrimus, kurių numatoma nauda tiriamam vaisiui viršija medicininę riziką (BTEI 3 str. 2 d.). Teisés aktuose nèra numatyta, kas turètų duoti sutikimą vykdyti tokius tyrimus.

Nei BTEIt, nei GKP taisyklès nepriskiria néščių ir žindančių moterų pažeidžiamų asmenų grupei ir neužtikrina joms pažeidžiamiems asmenims taikomos apsaugos. Tokį reguliavimą galima sieti su tuo, kad néštumas ir žindymas nèra laikomi būklèmis, dèl kurių moters kompetencija (gebejjimas) duoti laisvą ir informuotą sutikimą dalyvauti KVPT galètų būti kvestionuojama, t. y. neatitinka teisinio asmenų priskyrimo pažeidžiamiems asmenims kriterijaus. Be to, Lietuvos bioetikos komitetas, remdamasis galiojančia BTEI 5 str. 3 d., galètų něščiąsias (žindyves) pripažinti pažeidžiamais asmenimis ir tokiu būdu garantuoti joms (o kartu ir embrionui, vaisiui, kūdikiui) apsaugą, numatytą BTEI 7 straipsniu. Tačiau siekiant suderinti Lietuvos teisès aktus su visoje Europos Sąjungoje galiojančia leidimui atlikti KVPT gauti paraiškos forma, BTEI 5 str. turètų būti papildytas, ịtraukiant ì ji vaisingo amžiaus, néščias ir žindančias moteris.

\subsection{Pažeidžiamų asmenų apsaugos garantijos ir leidimų atlikti KVPT išdavimo ribojimas}

Ilgą laiką tyrimai su pažeidžiamais asmenimis buvo vangiai atliekami dèl vyraujančio požiūrio, kad tokie tyrimai yra neetiški. Priešinga nuomonė teigtų, kad neetiška nesuteikti galimybės pažeidžiamiems asmenims dalyvauti biomedicininiuose tyrimuose ir tokiu būdu gauti asmeninę ir / ar grupinę naudą, o įsitikinimas, kad kiti asmenys žino, kas yra geriausia

16 The PLoS Medicine Editors. Drug Development for Maternal Health Cannot Be Left to the Whims of the Market PLoS Med [interaktyvus]. 2008, 5(6): e140 [žiūrèta 2013-04-11]. <http://www.plosmedicine. org/article/metrics/info\%3Adoi\%2F10.1371\%2Fjournal.pmed.0050140;jsessionid=FC58B269178859 B36DD2CB536A1DF8DD>.

17 Europos Tarybos konvencija dèl žmogaus teisių ir orumo apsaugos biologijos ir medicinos taikymo srityje (Žmogaus teisių ir biomedicinos konvencija). Valstybès žinios. 2002, Nr. 97-425.

18 Embrionas - žmogaus organizmo vystymosi stadija nuo apvaisinimo momento (zigotos susidarymo) iki moters aštuntos nèštumo savaitès pabaigos (BETț 2 str. 4 d.).

19 Vaisius - žmogaus organizmo vystymosi stadija nuo moters devintos neeštumo savaitès pradžios iki gimimo (BETI 2 str. 15 d.).

20 Iltis, A. Who Is A Patient and Why Does It Matter? American Journal Of Bioethics. 2011, 11(5): 62-64.

${ }^{21}$ Chervenak, F.; McCullough, L. An Ethically Justified Framework for Clinical Investigation to Benefit Pregnant and Fetal Patients. American Journal Of Bioethics. 2011, 11(5): 39-49. 
pažeidžiamiesiems, gali reikšti pernelyg paternalistini požiūrị i juos ${ }^{22}$. KVPT turi atsakyti $\mathfrak{i}$ svarbų mokslinị klausimą, kad būtų pateisinamas ${ }^{23}$, t. y. galètų atnešti grupinę naudą tam tikrai asmenų populiacijai (tyrime gauti moksliniai duomenys ateityje pagerintų atitinkamos būklès pacientų gydymą). Todèl svarbu ne tik patenkinti pažeidžiamų asmenų poreikius biomedicininiuose tyrimuose, bet kartu - gerbti šių asmenų integralumą, neatliekant nereikalingų tyrimų (pvz., pasenusių, pasikartojančių) ${ }^{24}$. Be grupinès naudos, kurią gautų pažeidžiami asmenys dèl papildomų mokslinių duomenų ir patobulintų medicininių intervencijų, biomedicininiuose tyrimuose yra galima ir asmenine nauda: terapiné, edukaciné, autonomijos realizavimo, altruizmo ir visuomeniškumo išreiškimo ${ }^{25}$. Rizika, susijusi su pažeidžiamų asmenų dalyvavimu tyrime, turi būti minimizuota. Šias ir kitas KVPT, kuriuose dalyvauja pažeidžiamų asmenų grupès, sąlygas nustato tarptautiniai ir Lietuvos teisès aktai.

Pagal BTEI 7 str. 1 d. biomedicininius tyrimus su pažeidžiamais asmenimis leidžiama atlikti tik tuomet, kai laikomasi visų šių sąlygų: 1 ) tokị biomedicininị tyrimą galima atlikti tik su pažeidžiamais asmenimis; 2) biomedicininio tyrimo rezultatai gali tiesiogiai ir realiai pagerinti šiu tiriamųjų sveikatą; 3) biomedicininis tyrimas nesukels pavojaus tiriamojo sveikatai ar gyvybei. Reikalinga ịvertinti, kaip konkrečiose situacijose kiekviena iš BTEI 7 str. numatytų sąlygų gali riboti KVPT atlikimą su pažeidžiamais asmenimis.

Pirma BTEI 7 str. 1 d. ịtvirtinta biomedicininių tyrimų su pažeidžiamais asmenimis sąlyga numato, kad tyrimą galima atlikti tik tada, kai tokị biomedicininị tyrimą galima atlikti tik su pažeidžiamais asmenimis. Ji reiškia, kad, pavyzdžiui, psichikos ligonị draudžiama ịtraukti $\mathfrak{i}$ KVPT, kuriame néra nustatinejjamas tiriamojo preparato poveikis jo psichikos ligai, o vaikai negali dalyvauti tyrimuose, kuriuose nèra tiriama vaisto pediatrinè indikacija. Tokia norma iš pirmo žvilgsnio atitinka Direktyvos 2001/20/EB ir Oviedo konvencijos nuostatas, pagal kurias moksliniai tyrimai su asmenimis, neveiksniais duoti sutikimą, gali būti atliekami tik tada, kai panašaus veiksmingumo moksliniai tyrimai negali būti atlikti su asmenimis, veiksniais duoti sutikimą. Tačiau pasakytina, kad minèti tarptautiniai dokumentai kalba tik apie negalinčius duoti sutikimo asmenis. BTEI numato analogišką sąlygą tyrimams su visais pažeidžiamais asmenimis, o kartu ir su asmenimis, turinčiais psichikos sutrikimų, bet galinčiais duoti sutikimą dalyvauti biomedicininiame tyrime (BTEI 5 str. 1 d.1 p.). Todèl Lietuvoje, pavyzdžiui, cukriniu diabetu sergantis psichikos ligonis, kompetentingas duoti sutikimą, negalètų dalyvauti terapiniame diabeto tyrime, net jei toks tyrimas būtų naudingas jo sveikatai. Manytina, kad kompetentingų psichikos ligonių atžvilgiu aptariama nuostata yra pernelyg griežta ir nepagrịstai ribojanti tiriamiesiems naudingų tyrimų atlikimą bei jų ligų gydymui reikalingų vaistų kūrimą Lietuvoje.

Pagal antrą sąlygą, KVPT su pažeidžiamais asmenimis atlikti galima tik tada, kai jų rezultatai gali tiesiogiai ir realiai pagerinti šių tiriamųjų sveikatą. Taigi Lietuvoje pažeidžiamų asmenų atžvilgiu įtvirtintas tiesioginès ir realios naudos reikalavimas ${ }^{26}$. Pasakytina, kad BTEI nustatytą reikalavimą su pažeidžiamais asmenimis vykdyti tik terapinius tyrimus psichikos ligonių atžvilgiu dar kartą pabrèžia Psichikos sveikatos priežiūros ịstatymo 18 str. 3 d., pa-

22 Alexander, S. 'As long as it helps somebody': why vulnerable people participate in research. International Journal Of Palliative Nursing. 2010, 16(4):173-178.

23 Robert, $M$. Veatch. Indiference of subjects: an alternative to equipoise in randomized clinical trials. Social Philosophy and Policy. 2002, 19: 295-323.

24 Nordentoft, H.; Kappel, N. Vulnerable participants in health research: methodological and ethical challenges. Journal Of Social Work Practice. 2011, 25(3): 365-376.

25 Alexander, S., supra note 22.

26 Juškevičius J., supra note 6, p. 32. 
gal kurią klinikiniai eksperimentiniai gydymo metodai, psichochirurgija psichikos ligoniui gali būti taikomi tik gydymo tikslu. Oviedo konvencija laisviau nei BTEI reguliuoja asmenų, negalinčių duoti sutikimo, apsaugą, nes pagal Konvenciją individuali nauda tokiems tiriamiesiems gali būti tik potenciali, o išimtiniais atvejais su jais leidžiama atlikti minimalios rizikos tyrimus, net jeigu pats tiriamasis asmuo iš tyrimo naudos negaus - nauda gali būti siejama su „tokios pat būklès asmenų“ grupe ${ }^{27}$. Tokiu reguliavimu siekiama, kad pažeidžiami asmenys netaptų "terapiniais našlaičiais“ (angl. therapeutic orphans) ${ }^{28}$, kurių sveikatos sutrikimui nèra moksliškai pagrịsto gydymo. Pagal Tarptautinių sutarčių ịstatymo 11 str. 2 d., esant prieštaravimui tarp ratifikuotos sutarties ir nacionalinio įstatymo nuostatų, kolizija sprendžiama pirmosios naudai. Tačiau Oviedo konvencijos 27 str. ịtvirtina sutarties šalių diskreciją nusistatyti platesnio masto apsaugą biologijos ir medicinos taikymo srityje, negu nustatyta šioje Konvencijoje. Todèl BTEI numatyta griežtesnè KVPT dalyvaujančių pažeidžiamų asmenų apsauga neprieštarauja Lietuvos Respublikos tarptautiniams ịsipareigojimams. Vis dèlto ši teisès norma riboja tyrimų vykdymą, kai jų metu dar nèra patvirtinta terapinė nauda (nèra ịrodytas tiriamojo preparato veiksmingumas ir saugumas). I-II fazès tyrimai pagal šią normą negalètų būti atliekami su pažeidžiamais asmenimis (I fazès tyrimas - tai vaisto farmakologijos žmogaus organizme tyrimas, kuris neturi tikslo įvertinti gydomojo poveikio. II fazès KVPT metu siekiama nustatyti veiksmingas dozes, jų efektyvumą, gauti pirminius tiriamojo vaisto veiksmingumo ir saugumo įrodymus). III fazès tyrimų metu jau siekiama įsitikinti, kad vaistas yra veiksmingas ir saugus vartojant pagal tam tikrą indikaciją tam tikra liga sergantiems pacientams ${ }^{29}$, todėl $\mathfrak{i}$ šiuos tyrimus būtų leistina ịtraukti pažeidžiamus asmenis, jei dalyvavimas tyrime galètų realiai pagerinti jų sveikatą. Siekiant, kad vaistinių preparatų, reikalingų pažeidžiamų asmenų populiacijoms, kūrimas nebūtų nepagrịstai ribojamas, BTEI 7 str. 1 d. 3 p. tikslinga pakeisti, nustatant galimybę išimtiniais atvejais su pažeidžiamais asmenimis atlikti minimalios rizikos neterapinius tyrimus. Pasakytina, kad analogiškos nuostatos ittvirtintos pasauliniu mastu pripažistamose ir Lietuvoje negaliojančiose GKP taisyklèse negydomieji tyrimai galètų būti atliekami su tiriamaisiais, nekompetentingais duoti sutikimo, jeigu ịvykdytos GKP taisyklèse nustatytos sąlygos: minimali rizika sveikatai, tyrimo neįmanoma atlikti su asmenimis, galinčiais duoti sutikimą, to nedraudžia įstatymas, gautas atstovo sutikimas (GKP taisyklių 4.8.13 ir 4.8.14 p.).

Trečioji BTEI 7 str. įtvirtinta biomedicininių tyrimų su pažeidžiamais asmenimis sąlyga teigia, kad tyrimas turi nesukelti pavojaus tiriamojo sveikatai ar gyvybei. Ši nuostata galètu būti suprantama taip, kad pažeidžiami asmenys gali dalyvauti tyrime, kai jau yra gerai žinomas naudos ir rizikos santykis ir, jam esant palankiam, vaistas yra registruotas kaip saugus ir veiksmingas. Tačiau net ir registruoti vaistai yra susiję su tam tikra žalos sveikatai rizika (kiekvieno vaistinio preparato charakteristikų santraukoje yra aprašytos žinomos nepageidaujamos reakcijos). Taigi griežtai aiškinant šią nuostatą, pažeidžiamų asmenų nebūtų galima įtraukti ị jokius KVPT. Pagal Oviedo konvencijos 17 str. „minimalus pavojus ir minimali našta" yra galima tyrimuose su asmenimis, negalinčiais duoti sutikimo. Siekiant sudaryti palankias salygas pažeidžiamiems asmenims dalyvauti jiems naudinguose tyrimuose, BTEI

27 Europos Tarybos konvencija dèl žmogaus teisių ir orumo apsaugos biologijos ir medicinos taikymo srityje (Žmogaus teisių ir biomedicinos konvencija), supra note 17, 17 str.

28 Knoepffler, N. Research: ethical norms for medical research on humans. Bundesgesundheitsblatt, Gesundheitsforschung, Gesundheitsschutz [interaktyvus]. 2008 [žiūrèta 2013-04-11]. <http://www.ncbi. nlm.nih.gov/pubmed/18787866>.

29 Stakišaitis, D., et al. Gera klinikine praktika. Metodinès rekomendacijos tyrejui. Vilnius: BSPB spaustuvè, 2005, p. 38-40. 
vartojamą „pavojaus tiriamojo sveikatai ar gyvybei“ sąvoką būtina patikslinti, nurodant, kokio lygio pavojus yra nepriimtinas tyrimuose su pažeidžiamais asmenimis.

Pažeidžiamiems asmenims taikomų KVPT reikalavimų turi laikytis visi tyrimus vykdantys asmenys - užsakovas turi pareigą užtikrinti, kad tyrimo su pažeidžiamais asmenimis protokolas atitinka visas BTEI 7 str. įtvirtintas sąlygas, KVPT metu vykdyti nustatytų reikalavimų laikymosi priežiūrą (GKP taisyklių 5.1.1 ir kt. punktai); tyrèjas, ịtraukdamas kiekvieną konkretų pažeidžiamą asmenị ị tyrimą, turi ịvertinti, ar galima jo atžvilgiu tikètis terapinès naudos, ar tyrimas nesukels pavojaus jo sveikatai (GKP taisyklių 4.1.3, 4.3.1 ir kt. punktai). Be to, jeigu leidimui ar pritarimui atlikti KVPT gauta paraiškos forma ir su ja pateikti dokumentai neatitiktų BTEI nustatytų reikalavimų, Valstybinè vaistų kontrolès tarnyba ir Lietuvos bioetikos komitetas negalètu išduoti pritarimo ir leidimo atlikti KVPT ${ }^{30}$. Todèl anksčiau pateikti siūlymai dèl perteklinių ir nepagrịstai KVPT atlikimą varžančių nuostatų pakeitimo yra aktualūs tyrimų dalyviams (pažeidžiamų asmenų grupèms), juos vykdantiems asmenims (užsakovams, tyrëjams) bei kontrolès institucijoms.

\section{Psichikos ligonių sutikimas}

\subsection{Psichikos sutrikimą turinčio asmens ir psichikos ligonio sąvokos teisès aktuose}

2 lentelè. VVKT svarstytų paraiškų leidimui atlikti psichiatrinị tyrimą gauti skaičius nuo 2004 iki $2012 \mathrm{~m}^{31}$

\begin{tabular}{|l|c|c|c|c|c|c|c|c|c|}
\hline Metai & 2004 & 2005 & 2006 & 2007 & 2008 & 2009 & 2010 & 2011 & 2012 \\
\hline Paraiškų sk. & 7 & 5 & 4 & 11 & - & 3 & 10 & 7 & 5 \\
\hline
\end{tabular}

Psichiatriniuose tyrimuose kyla ịvairios etinès problemos (pavyzdžiui, susijusios su konfidencialumo užtikrinimu, placebo skyrimu), tačiau daugiausiai etinių diskusijų kelia psichikos ligonio informuotas sutikimas dalyvauti tyrime. ${ }^{32,33}$ Istatymų nuostatose, reglamentuojančiose psichikos ligonių sutikimą dalyvauti biomedicininiame tyrime, vartojamos skirtingas sąvokos šiai pažeidžiamų asmenų grupei apibūdinti. Psichikos sveikatos priežiūros ịstatymo 18 str. $3 \mathrm{~d}$. vartojama psichikos ligonio sąvoka ${ }^{34}$, o analogiškoje nuostatoje, ịtvirtintoje BTEI 7 str. 3 d., - psichikos sutrikimą turinčio asmens sąvoka. Psichikos sutrikimo sąvoka nèra apibrèžta teisès aktuose, tačiau psichikos ir elgesio sutrikimai yra išvardinti Lietuvoje galiojančios Tarptautinès ligų klasifikacijos TLK-10 5-ame skyriuje ${ }^{35}$. Aiškinant Psichikos sveikatos priežiūros įstatymo 2 str. pateikiamus apibrèžimus, galima daryti išvadą,

30 Lietuvos Respublikos farmacijos įstatymas supra note 4, 4 straipsnio 11 dalis.

31 Informacija apie klinikinius tyrimus Lietuvoje 2012 metais. Valstybinè vaistų kontrolès tarnyba prie Lietuvos Respublikos sveikatos apsaugos ministerijos [interaktyvus]. Vilnius, 2012 [žiūrèta 2013-0418]. < http://www.vvkt.lt/Metines-suvestines $>$.

32 Osborn, D. P.; Fulford, K. W. Psychiatric research: what ethical concerns do LRECs encounter? J Med Ethics. 2003, 29: 55-56.

33 Serretti, A.; Artioli, P. Ethical problems in pharmacogenetic studies of psychiatric disorders. The Pharmacogenomics Journal. 2006, 6: 1-7.

34 Lietuvos Respublikos psichikos sveikatos priežiūros ịstatymas. Valstybės žinios. 1995, Nr. 53-1290.

35 Tarptautinès statistinès ligų ir sveikatos sutrikimų klasifikacijos dešimtasis pataisytas ir papildytas leidimas Australijos modifikacija. TLK-10-AM [interaktyvus]. Sidnejjus, Nacionalinis medicininès klasifikacijos centras, 2008 [žiūrèta 2013-06-19]. <http://ebook.vlk.lt/e.vadovas/index.jsp>. 
kad psichikos ligonio statusą asmuo ịgyja nuo to momento, kai jo medicinos dokumentuose gydytojas psichiatras oficialiai užfiksuoja psichikos ligos diagnozę, ịtvirtintą tarptautinès ligų klasifikacijos TLK-10-AM 5 skyriuje. „Todèl netgi ir tokių būsenų, kurias daugelis žmonių savo gyvenime yra patyrè (pavyzdžiui, košmariški sapnai (TLK-10-AM-F51.5), naktinis siaubas (TLK-10-AM-F51.4), emocinis miego sutrikimas (TLK-10-AM-F51.9) ir pan.), diagnozavimas tampa formaliu pagrindu asmenį laikyti psichikos ligoniu“ ${ }^{\text {“36. }}$. Manytina, kad specialios apsaugos biomedicininiuose tyrimuose nustatymui tai yra pernelyg platus asmenu ratas.

Psichikos ligonio sutikimo dalyvauti KVPT problematika susijusi su rizika, jog psichikos liga gali neigiamai paveikti intelektualinị arba valinị sutikimą duodančio asmens kompetencijos aspektą. Psichikos sveikatos priežiūros i̇statymo 18 str. 3 d. nustato, kad klinikiniai eksperimentiniai gydymo metodai, psichochirurgija gali būti taikomi tik jeigu ligonis tai sąmoningai suprato ir davé raštišką sutikimą. BTEI 5 str. 1 d. pažeidžiamų asmenų grupei priskiria asmenis, turinčius psichikos sutrikimų, bet galinčius duoti sutikima dalyvauti biomedicininiame tyrime, BTEI 7 str. 3 d. nustato reikalavimus asmenų, turinčių psichikos sutrikimų, bet galinčiu duoti sutikima, sutikimo procedūrai. Taigi pagal Lietuvos Respublikos ịstatymus su psichikos ligoniu atlikti KVPT leidžiama tik tuo atveju, kai jis yra kompetentingas, t. y. gali sąmoningai suprasti ir pats duoti sutikimą dalyvauti tyrime. Tiek Oviedo konvencijos 17 str., tiek Direktyvos 2001/20/EB5 str. papildoma apsauga numatyta asmenims, negalintiems duoti sutikimo ${ }^{37}$, o su psichikos ligoniais, galinčiais duoti sutikimą, KVPT gali būti vykdomi be papildomų apsaugos garantijų. Oviedo konvencija ir Direktyva 2001/20/EB leidžia nustatyti griežtesnius reikalavimus, nei numatyti šiuose tarptautiniuose dokumentuose, todèl BTEl̨ ir psichikos sveikatos priežiūros įstatymo reikalavimai, netiesiogiai draudžiantys su nekompetentingais psichikos ligoniais vykdyti tyrimus, nepažeidžia Lietuvos tarptautinių i̇sipareigojimų.

Lietuvos îstatymuose nustatytas draudimas įtraukti $\mathfrak{i}$ tyrimus psichikos ligonius, nekompetentingus duoti sutikimą, sietinas su Lietuvos Respublikos Konstitucijos 21 str., pagal kurị „Su žmogumi, be jo žinios ir laisvo sutikimo, negali büti atliekami moksliniai ar medicinos bandymai." Tačiau pagal Civilinio kodekso 2.133 str. $1 \mathrm{~d}$. atstovas sandorius sudaro atstovaujamojo vardu - atstovo sutikimas teisine prasme yra prilyginamas paties atstovaujamojo asmens sutikimui. Todel galima manyti, kad teisinis reguliavimas, leidžiantis nekompetentingą asmenị ịtraukti $\mathfrak{i}$ tyrimą be jo paties kompetentingo sutikimo, bet gavus tinkamai išreikštą jo atstovo(-ų) sutikimą, neprieštarautų minètai Konstitucijos nuostatai. Tokio reguliavimo pavyzdys yra galiojančios BTEI 7 str. 2 d. nuostatos dèl nepilnamečių atstovavimo duodant sutikimą jiems dalyvauti biomedicininiuose tyrimuose. BTĘ ir Psichikos sveikatos priežiūros ístatyme vartojamos psichikos ligonio ir psichikos sutrikimą turinčio asmens sąvokos turètų būti suvienodintos ir susiaurintos, susiejant jas su psichikos ligonio nekompetencija (negalëjimu) duoti sutikimą dalyvauti tyrime.

\subsection{Psichikos ligonio kompetencijos vertinimas}

Pagal Lietuvoje galiojančius ịstatymus prieš pradedant psichikos ligonio sutikimo dalyvauti KVPT procedūrą reikalinga ịsitikinti, kad jis yra kompetentingas (galintis duoti sąmo-

36 Benkunskas, V. Psichikos sveikatos priežiūros terminų vartojimo teisiniame reglamentavime probleminiai aspektai. Sveikatos politika ir valdymas. 2012, 1(4): 163-184.

37 Europos Tarybos konvencija dèl žmogaus teisių ir orumo apsaugos biologijos ir medicinos taikymo srityje (Žmogaus teisių ir biomedicinos konvencija), supra note 17, 17 str. 
ningą sutikimą), tačiau teisės normos nereguliuoja, kaip turi būti atliekamas šis vertinimas. Ši teisès spraga apsunkina tyrimų vykdymą ir jų kontrolę (tyrèjams nėra aišku, kaip turi būti nustatyta psichikos ligonio kompetencija; GKP inspektoriams nèra galimybių patikrinti, ar kompetencija buvo nustatyta tinkamai), taip pat negali užtikrinti reikiamos psichikos ligonių apsaugos tyrimuose. Psichikos ligonio kompetencijos vertinimo problematika yra plačiai nagrinejjama užsienio šalių mokslinèje literatūroje, kompetencijos vertinimo metodikos taikomos psichiatrų praktikoje bei atsispindi kitų valstybių teisès aktuose, oficialiose tyrimų vykdymo rekomendacijose.

Asmenys, sergantys psichikos ligomis, kompetencijos (gebejjimas, galejimas) duoti sutikimą dalyvauti tyrime prasme nèra homogeniška grupe $\dot{e}^{38}$. Net ir sunkia psichikos liga sergantis asmuo per se neturètų būti laikomas nekompetentingu ${ }^{39}$. Itvairūs tyrimai rodo, kad tik maža procentinè psichikos ligonių dalis yra nekompetentingi priimti sprendimus, susijusius su gydymu ar dalyvavimu tyrime. Prieš atliekant sutikimo procedūrą, pacientui gali būti užduodami keli trumpi klausimai, iš kurių matytųsi, ar reikalinga kvestionuoti asmens kompetenciją ir atlikti išsamų jos vertinimąa ${ }^{40}$. Psichikos ligonis gali būti nekompetentingas priimti sudètingus sprendimus, bet gebèti priimti paprastesnius. Taip pat to paties asmens kompetencija yra nevienoda skirtingose sprendimų priemimo sferose (srityse) ${ }^{41}$. Todèl kompetencijos priimti medicininị sprendimą vertinimas turètų būti kiek įmanoma labiau specializuotas, pritaikytas konkrečiam atvejui ${ }^{42}$. Reikalaujamas kompetencijos lygis turètų priklausyti nuo informacijos apie tyrimą sudètingumo ir tyrimo rizikos, o kompetencijos vertinimo metodai turètų apimti klausimus apie numatomą atlikti tyrimą ${ }^{43}$ (kokie yra tyrimo tikslai; kurie tyrimo aspektai yra eksperimentinio pobūdžio - ką siekiama nustatyti tyrime; galima rizika ir nauda; kokios yra galimos dalyvavimo tyrime alternatyvos) ${ }^{44}$. Psichikos ligonio kompetencija duoti sutikimą dalyvauti biomedicininiame tyrime dažnai yra kintanti ${ }^{45,46}$. Todèl ilgalaikio tyrimo metu pasikeitus reikšmingai informacijai apie tyrimą (kai būtina iš naujo gauti informuotą tiriamųjų sutikimą pagal GKP taisyklių 4.8.2, 4.8.11 p.), rizikos grupei priklausančių psichikos ligonių kompetencija turètų būti vertinama pakartotinai.

38 Dunn, L. B. Capacity to Consent to Research in Schizophrenia: The Expanding Evidence Base. Behavioral Sciences and the Law. 2006, 24: 431-445.

39 Saks, E. R.; Jeste, D. V. Capacity to Consent to or Refuse Treatment and/or Research: Theoretical Considerations. Behavioral Sciences and the Law. 2006, 24: 411-429.

40 Palmer, B. W. Informed Consent for Schizophrenia Research: What is an Investigator (or IRB) to Do? Behavioral Sciences and the Law. 2006, 24: 447-452.

${ }^{41}$ Dunn, L. B., supra note 38, p. 431.

42 Lantz, M. S. The Mac CAT-T for Evaluation of Decision-Making Capacity. Clinical Geriatrics. 2006, 14(2): 15-18.

43 Dunn, L. B., supra note 38, p. 434-435.

44 Research Involving Individuals with Questionable Capacity to Consent: Points to Consider. U.S. Department of Health and Human Services [interaktyvus]. Bethesda, 2009 [žiūrèta 2013-06-30]. <http:// grants1.nih.gov/grants/policy/questionablecapacity.htm>.

45 Huthwaite, S. J., et al. Declining Medical Decision-Making Capacity in Mild AD: A Two-Year Longitudinal Study. Behavioral Sciences and the Law. 2006, 24: 453-463.

46 Moser, D., et al. Informed consent in medication-free schizophrenia research. American Journal of Psychiatry. 2005, 162: 1209-1211. 
Užsienyje yra sukurta ne mažiau kaip 10 ịvairių metodikų, skirtų nustatyti psichikos ligonio kompetenciją duoti sutikimą dalyvauti klinikiniame tyrime ${ }^{47,48,49,50}$. Dažniausiai yra vertinami keturi kompetencijos elementai (gebejimai): supratimas (angl. understanding), sietinas su pasirinkimui svarbios informacijos žinojimu; suvokimas (angl. appreciating) - galejjimas pateiktą informaciją pritaikyti savo atžvilgiu, numatyti pasirinkimo pasekmes; samprotavimas (angl. reasoning) - gebejjimas argumentuoti, logiškai pagrịsti savo pasirinkimą ir pasirinkimo išreiškimas (angl. evidencing a choice) - galejjimas išreikšti savo apsisprendimą ${ }^{51}$. Kiekvieno iš šių gebejimų samprata ir ribos yra diskutuotini, o jų vertinimo reikalingumas ir reikalaujamas manifestacijos lygis konkrečiu atveju turètų priklausyti nuo sprendimo konteksto (KVPT, psichikos sutrikimo pobūdžio) ir sprendimo svarbos (su sprendimu susijusios rizikos) pačiam ligoniui ${ }^{52}$.

Kompetencija duoti informuotą sutikimą paprastai yra siejama su „gebejjimu suprasti“ informaciją (pvz., Psichikos sveikatos priežiūros įstatymo 18 str. 3 d. vartojama sąvoka „sąmoningai suprato“), todèl literatūroje, nagrinèjančioje psichikos ligonių kompetenciją priimti sprendimus, yra dažniausiai kalbama apie asmenis, turinčius kognityvinius sutrikimus. Šis požiūris dažniausiai pasiteisina, nes kognityvinių gebejjimų deficitas stipriai koreliuoja su nekompetencija priimti sprendimus ${ }^{53}$. Vyrauja nuomonè, kad asmuo, suprantantis atitinkamo reiškinio naudą ir riziką, pasirinktų tai, kas maksimizuotų naudą ir minimizuotų žalą jo paties atžvilgiư ${ }^{54}$. Tačiau vertinant psichikos ligonio kompetenciją duoti sutikimą dalyvavimui tyrime, svarbu atsižvelgti ir $\mathfrak{i}$ tai, kad didele psichikos sutrikimus turinčių asmenų subpopuliacija kenčia nuo patologijų, kurios verčia juos kenkti sau arba siekti, kad kiti asmenys juos žalotų. Tai sietina ne su intelektualiniu (kognityviniais gebejjimais, galejjimu suprasti informaciją), bet su valiniu (emociniu ir motyvaciniu) kompetencijos aspektu ${ }^{55}$. Pavyzdžiui, depresija sergantys pacientai paprastai yra laikomi kompetentingais duoti sutikimą dalyvauti KVPT, nes depresija nepaveikia asmens kognityvinių gebejimų ${ }^{56}$. Tačiau sunkia depresijos forma sergantis asmuo gali suprasti tyrimo riziką, bet neteikti jai didelès reikšmès ir ì ją neatsižvelgti. Suicidinių (savižudybės) minčių turintis asmuo gali sutikti dalyvauti tyrime, tikèdamasis, kad tyrimo procedūros padarys žalą jo sveikatai ar net sukels mirtị ${ }^{57}$. Ilgalaikis sveikatos pagerejjimas ar dar abstraktesnè nauda - altruistinis pasiaukojimas visuomenès ir mokslo labui - šiems asmenims gali būti ne tiek svarbūs, kiek jų „dabartiniai“ psichologiniai poreikiai. Kaip nepagrịstas tikejimas, kad dalyvavimas tyrime bus naudingas sveikatai

47 Dunn, L. B., supra note 38, p. 435.

48 Jeste, D. V., et al. A New Brief Instrument for Assessing Decisional Capacity for Clinical Research. Arch Gen Psychiatry. 2007, 64(8): 966-974.

49 Hickman, N.; Prochaska, J.; Dunn, L. Screening for Understandingo of Research in the Inpatient Psychiatry Setting. Journal Of Empirical Research On Human Research Ethics. 2011, 6(3):65-72.

50 Saks, E. R.; Dunn, L. B.; Marshall, B. J.; Nayak, G. V.; Golsan, S.; Jeste, D. V. The California Scale of Appreciation: A New Instrument to Measure the Appreciation Component of Capacity to Consent to Research. American Journal of Geriatric Psychiatry. 2002, 10: 166-174.

51 Dunn, L. B., supra note 38, p. 435.

52 Saks, E. R.; Jeste, D. V., supra note 39, p. 412.

53 Dunn, L. B., supra note 38, p. 437.

54 Dew, R. E. Informed consent for research in Borderline Personality Disorder. BMC Medical Ethics. 2007, 8: 4.

55 Elliott, C. Caring about Risks. Are Severely Depressed Patients Competent to Consent to Research? Arch Gen Psychiatry. 1997, 54(2): 113-116.

$56 \quad$ Ibid.

57 Dew, R. E., supra note 56. 
(angl. therapeutic misconseption) ${ }^{58}$, taip ir šie psichologiniai poreikiai turètų būti laikomi aplinkybėmis, trukdančiomis asmeniui duoti kompetentingą sutikimą dalyvauti KVPT, nes neadekvati motyvacija iškreiptų valinị kompetencijos aspektą (GKP taisyklių 1.61 p.).

Kai kuriais atvejais informacijos apie tyrimą neteisingo suvokimo priežastis yra ne paciento kompetencijos stoka, bet netinkamas informacijos pateikimas ${ }^{59}$. Psichikos ligonio kompetencija gali būti koreguojama - ịvairūs metodai, kuriais siekiama pagerinti asmens gebejimą duoti sutikimą dalyvauti tyrime, dažnai pasiteisina ${ }^{60,61,62,63}$. Du ar tris kartus atliekamas kompetencijos vertinimas prieš tai pakartotinai pateikiant svarbią informaciją apie tyrimą ir koreguojamas grįžtamasis ryšys (informacijos patikslinimas, paaiškinimas, atsižvelgiant ị tai, kurie klausimai pacientui buvo sudètingiausi) gali reikšmingai pagerinti gebẻjimą duoti sutikimą dalyvauti tyrime ${ }^{64}$. Psichikos ligoniai taip pat lengviau supranta informaciją apie KVPT, pateiktą struktūrizuota forma arba naudojant kompiuterines prezentacijas, edukacinę videomedžiagą ${ }^{65}$. Todèl sutikimo procese tikslinga daugiau dèmesio skirti tam, kaip tyrejas galètų efektyviau komunikuoti su potencialiais tyrimo dalyviais, sergančiais psichikos ligomis ${ }^{66}$.

Apžvelgti psichikos ligonio kompetencijos vertinimo aspektai turètų būti detalizuoti teisés aktuose ar metodinèse rekomendacijose tyrejjams. Nustatant taisykles kompetencijos vertinimo procesui svarbu išlaikyti tam tikrą pusiausvyrą - nekompetentingas asmuo negali duoti autonomiško sutikimo dalyvauti tyrime ${ }^{67}$, jo įtraukimas i tyrimą prieštarautu biomedicininių tyrimų etikai ${ }^{68}$ ir pažeistų Lietuvos Respublikos ịstatymus, tačiau itin aukšti kompetencijos standartai ne tik apribotų psichikos ligonių autonomiją, prisidètų prie jų stigmatizacijos, bet taip pat daliai iš jų atimtų galimybę dalyvauti tyrimuose, kurie jiems būtų naudingi ${ }^{69}$.

\subsection{Psichikos ligonių sutikimo procese dalyvaujantys asmenys}

Pagal BTEI 7 str. 3 d. ir Psichikos sveikatos priežiūros ịstatymo 18 str. 3 d. du liudytojai ir sveikatos priežiūros isstaigos, kurioje vykdomas tyrimas, vadovas turi patvirtinti psichikos ligonio sutikimą ${ }^{70,71}$. GKP taisykliu 1.26 p. nešališką liudininka apibrěžia kaip nepriklausantį nuo tyrimo asmenį, kurio negalètų bet kokiu büdu paveikti su tyrimu susiję as-

58 Henderson, G. E., et al. Clinical Trials and Medical Care: Defining the Therapeutic Misconception. PLo S Medicine. 2007, 4:1735-1738.

59 Lidz, Ch. W. The Therapeutic Misconception and Our Models of Competency and Informed Consent. Behavioral Sciences and the Law. 2006, 24: 535-546.

60 Dunn, L. B., supra note 38, p. 434.

${ }_{61}$ Carpenter, W. T., et al. Decisional Capacity for Informed Consent in Schizophrenia Research. Archives of General Psychiatry. 2000, 57: 533-538.

62 Dunn, L. B., et al. Improving Understanding of Research Consent in Middle-Aged and Elderly Patients with Psychotic Disorders. American Journal of Geriatric Psychiatry. 2002, 10: 142-150.

63 Palmer, B. W., et al. Correlates of Treatment-Related Decision-Making Capacity among Middle-Aged and Older Patients with Schizophrenia. Archives of General Psychiatry. 2004, 61: 230-236.

${ }_{64}$ Dunn, L. B., supra note 38, p. 439.

65 Ibid., p. 440.

66 Palmer, B. W., supra note 41, p. 451.

67 Saks, E. R.; Jeste, D. V., supra note 39, p. 412.

68 Dunn, L. B., supra note 38, p. 431.

69 Saks, E. R.; Jeste, D. V., supra note 39, p. 425.

70 Lietuvos Respublikos biomedicininių tyrimų etikos ịstatymas, supra note 5.

${ }^{71}$ Lietuvos Respublikos psichikos sveikatos priežiūros ịstatymas, supra note 34. 
menys $s^{72}$. Atsižvelgiant ị tai galima teigti, jog liudytojas turi būti nepriklausomas nuo tyrimą vykdančių asmenų (pagrindinio tyrèjo, tyrèjų, tyrimo užsakovų, prižiūrètojų ar kitų su tyrimu susijusių asmenų) bei nesusaistytas su šiais asmenimis jokiais ryšiais (pavaldumo, giminystès, santuokos ir kt.) ${ }^{73}$. GKP taisyklių 4.8.9 p. nustato, kad nešališkas liudytojas, pasirašydamas informuoto asmens sutikimo formą, patvirtina, kad pateikta informacija buvo tiksliai išaiškinta tiriamajam arba jo teisètam atstovui, kurie teisingai ją suprato, ir jų sutikimas, susipažinus su ta informacija, buvo duotas laisva valia. Iš sisteminès teisés normu analizès galima daryti išvadą, kad ir sveikatos priežiūros ịstaigos vadovas turi asmeniškai dalyvauti tiriamųjų asmenų sutikimo procese, stebėti ir ịvertinti, ar buvo tinkamai vykdoma teisès aktuose nustatyta sutikimo procedūra (ar dalyvavo nešališki liudytojai, ar informacija buvo išaiškinta tiriamajam, ar jis davè sąmoningą sutikimą) $)^{74}$.

BTEI 7 str. 3 d. ir Psichikos sveikatos priežiūros istatymo 18 str. 3 d. nustato, kad su psichikos ligoniais gali būti atliekami tyrimai tik medicinos etikos komisijai prižiūrint ir esant jos pritarimui ${ }^{75,76}$. Kvestionuotina, ar sveikatos priežiūros įstaigos viduje veikianti komisija, kurios nariai yra pavaldūs vadovui, galètų priimti nepriklausomą sprendimą dèl psichikos ligonio dalyvavimo tyrime, kai ligonio sutikimą dalyvauti tyrime patvirtintų (ar nepatvirtintų) ístaigos vadovas. Taip pat neaišku, ar komisijos pritarimas reikalingas dèl kiekvieno psichikos ligonio ịtraukimo ị tyrimą, ar užtenka bendro pritarimo dèl viso tyrimo, planuojamo vykdyti toje psichikos sveikatos priežiūros įstaigoje. Teisès aktuose būtina detalizuoti šiuos ir kitus medicinos etikos komisijos veiklos aspektus.

Nors psichikos ligonis turi duoti asmeninị, sąmoningą (kompetentingą) sutikimą dalyvauti tyrime, svarbu atkreipti demesị $\mathfrak{i}$ Civilinio kodekso 2.25 str. 1 d., kuri nustato, kad su neveiksniu asmeniu negali būti atliekami jokie moksliniai, medicinos bandymai ar tyrimai be jo atstovo sutikimo ${ }^{77}$. Todèl tais atvejais, kai psichikos ligonis yra teismo pripažintas neveiksniu, be jo paties sutikimo, reikalingas ir jo teisèto atstovo sutikimas dèl asmens įtraukimo ị KVPT.

Kaip matyti iš anksčiau minètų teisės aktų reikalavimų, Lietuvoje psichikos ligoniams yra taikoma ypatingai griežta apsauga tyrimuose: su psichikos ligoniais leidžiami tik terapiniai, nekeliantys pavojaus KVPT; be paties psichikos ligonio, sutikimo procese turi dalyvauti du liudytojai, sveikatos priežiūros įstaigos vadovas, psichikos ligonio atstovas (kai tiriamasis neveiksnus), medicinos etikos komisija; taip pat ši komisija turi vykdyti tyrimo priežiūrą. İvertinant tai, kad pats psichikos ligonis turi būti kompetentingas ir duoti asmeninị, sąmoningą sutikimą dalyvauti tyrime, kai kurios iš išvardintų apsaugos garantijų šių asmenų atžvilgiu yra laikytinos perteklinėmis (pvz., ịstaigos vadovo pritarimas sutikimui) ar pernelyg griežtomis (pvz., reikalavimas ịtraukti pažeidžiamus asmenis tik ị terapinius tyrimus). Be

72 Lietuvos Respublikos sveikatos apsaugos ministro 1998 m. birželio 12 d. ịsakymu Nr. 320 patvirtintos Geros klinikinès praktikos taisyklès, supra note 11.

73 DUK. Kokie asmenys gali būti liudytojais ir koks jų vaidmuo, ịtraukiant ị biomedicininị tyrimą asmenį, sergantị psichikos liga, bet galintị sąmoningai sutikti dalyvauti biomedicininiame tyrime? Lietuvos bioetikos komitetas [interaktyvus]. Vilnius, 2012 [žiūrèta 2013-05-19] <http://bioetika.sam.lt/index. php?1502207870>.

74 DUK. Koks sveikatos priežiūros įstaigos vadovo vaidmuo, patvirtinant asmens, sergančio psichikos liga, bet galinčio sąmoningai sutikti dalyvauti biomedicininiame tyrime, sutikimą? Lietuvos bioetikos komitetas [interaktyvus]. Vilnius, 2012 [žiūreta 2013-05-19]. <http://bioetika.sam.lt/index.php?1429531234>.

75 Lietuvos Respublikos biomedicininių tyrimų etikos ịstatymas, supra note5.

76 Lietuvos Respublikos psichikos sveikatos priežiūros įstatymas, supra note 34.

77 Lietuvos Respublikos civilinio kodekso patvirtinimo, įsigaliojimo ir igyvendinimo įstatymas. Civilinis kodeksas. Valstybès žinios. 2000, Nr. 74-2262. 
to, minèti reikalavimai nèra detalizuoti ịstatymus iggvendinančiuose teisės aktuose, neaišku, kaip šios teisės normos turi būti vykdomos. Toks reguliavimas apsunkina ne tik psichiatrinių KVPT vykdymą Lietuvoje, bet ir VVKT atliekamą tyrimų kontrolę. Dèl to analizuojamos teisės normos praktikoje negali tinkamai užtikrinti psichikos ligonių apsaugos tyrimuose ir turi būti tobulinamos.

\section{Išvados}

1. BTEI ir GKP taisyklèse pateikiami pažeidžiamų asmenų sąrašai nesutampa, be to, jie neapima visų leidimui atlikti KVPT gauti paraiškoje nurodytų pažeidžiamųjų asmenų grupių. BTEI 5 str. turètų būti papildytas, ịtraukiant i jị vaisingo amžiaus, néččias ir žindančias moteris.

2. BTEI 7 str. nustatytos papildomos pažeidžiamų asmenų apsaugos garantijos yra perteklinès ir nepagrịstai varžančios tyrimų atlikimą Lietuvoje. BTEI 7 str. 1 d. 2 p. tikslinga pakeisti, nustatant galimybę išimtiniais atvejais su pažeidžiamais asmenimis atlikti neterapinius tyrimus. BTEI 7 str. 1 d. 3 p. vartojama "pavojaus tiriamojo sveikatai ar gyvybei“ sąvoka turètų būti paaiškinta teisès aktuose, nurodant, kokio lygio pavojus yra nepriimtinas tyrimuose su pažeidžiamais asmenimis.

3. Lietuvoje psichikos ligonių atžvilgiu tyrimų vykdymo reikalavimai itin griežti - su negalinčiais duoti sutikimo psichikos ligoniais tyrimus atlikti draudžiama, o psichikos ligoniai, kompetentingi duoti sutikimą, priskiriami pažeidžiamiems asmenims ir jiems taikomos perteklinės, psichiatrinių tyrimų vykdymą apsunkinančios apsaugos garantijos. BTĘ̨ ir Psichikos sveikatos priežiūros įstatyme vartojamos psichikos ligonio ir psichikos sutrikimą turinčio asmens sąvokos turètų būti suvienodintos ir susiaurintos, susiejant jas su psichikos ligonio nekompetencija duoti sutikimą dalyvauti tyrime. Nesant teisės normų, detalizuojančių BTEI 7 str. 3 d. ir Psichikos sveikatos priežiūros ịstatymo 18 str. 3 d., neaišku, kaip jose nustatytos garantijos turi būti ígyvendinamos ir kaip vykdoma šių teisės normų laikymosi kontrolè. Dèl to minèti ịstatymai negali užtikrinti tinkamos psichikos ligonių apsaugos tyrimuose ir turi būti tobulinami.

4. Pagal galiojančius teisès aktus ịtraukiant psichikos ligonị ị tyrimą būtina ịsitikinti, kad jis yra kompetentingas (galintis duoti sąmoningą sutikimą). Valstybè turètų nustatyti psichikos ligonio kompetencijos vertinimo taisykles, nes jų nebuvimas apsunkina tyrimų vykdymą ir kontrolę, taip pat negali užtikrinti reikiamos psichikos ligonių apsaugos tyrimuose. Psichikos ligonio kompetencijos vertinimo procesas turètų būti kiek ịmanoma labiau specializuotas, apimti intelektualinị ir valinị kompetencijos aspektą. Reikalaujamas kompetencijos lygis turètų priklausyti nuo informacijos apie tyrimą sudètingumo ir tyrimo rizikos. Sutikimo procese tikslinga pasitelkti metodus, kurie gali pagerinti asmens gebejjimą duoti sutikimą dalyvauti tyrime.

\section{Literatūra}

1. $2001 \mathrm{~m}$. balandžio 4 d. Europos Parlamento ir Tarybos direktyva 2001/20/EB dèl valstybiu narių ỉstatymų ir kitų teisès aktų, susijusių su geros klinikinès praktikos igyvendinimu atliekant žmonèms skirtų vaistų klinikinius tyrimus, suderinimo. [2001] OL L 121/34.

2. $2005 \mathrm{~m}$. balandžio 8 d. Komisijos direktyvos 2005/28/EB, nustatančios geros klinikinès praktikos, susijusios su tiriamaisiais žmonėms skirtais vaistais, principus bei išsamias gaires ir leidimui gaminti ir importuoti tokius vaistus keliamus reikalavimus. [2005] OL L91/13. 
3. Alexander, S. 'As long as it helps somebody': why vulnerable people participate in research. International Journal of Palliative Nursing. 2010, 16(4): 173-178.

4. Carpenter, W. T., et al. Decisional Capacity for Informed Consent in Schizophrenia Research. Archives of General Psychiatry. 2000, 57: 533-538.

5. Chervenak, F.; McCullough, L. An Ethically Justified Framework for Clinical Investigation to Benefit Pregnant and Fetal Patients. American Journal Of Bioethics. 2011, 11(5): 39-49.

6. Dew, R. E. Informed consent for research in Borderline Personality Disorder. BMC Medical Ethics. 2007, 8: 4.

7. DUK. Kokie asmenys gali būti liudytojais ir koks jų vaidmuo, ịtraukiant ị biomedicininị tyrimą asmení, sergantị psichikos liga, bet galintị sąmoningai sutikti dalyvauti biomedicininiame tyrime? Lietuvos bioetikos komitetas [interaktyvus]. Vilnius, 2012 [žiūrèta 2013-05-19]. <http://bioetika.sam.lt/index.php?1502207870>.

8. DUK. Koks sveikatos priežiūros įstaigos vadovo vaidmuo, patvirtinant asmens, sergančio psichikos liga, bet galinčio sąmoningai sutikti dalyvauti biomedicininiame tyrime, sutikimą? Lietuvos bioetikos komitetas [interaktyvus]. Vilnius, 2012 [žiūrèta 2013-0519]. <http://bioetika.sam.lt/index.php?-1429531234>.

9. Dunn, L. B., et al. Improving Understanding of Research Consent in Middle-Aged and Elderly Patients with Psychotic Disorders. American Journal of Geriatric Psychiatry. 2002, 10: 142-150.

10. Dunn, L. B. Capacity to Consent to Research in Schizophrenia: The Expanding Evidence Base. Behavioral Sciences and the Law. 2006, 24: 431-445.

11. Elliott, C. Caring about Risks. Are Severely Depressed Patients Competent to Consent to Research? Arch Gen Psychiatry. 1997, 54 (2):113-116.

12. Europos Komisijos 2010 m. kovo 30 d. išsamios gairès 2010/C 82/01 dèl prašymų gauti kompetentingos institucijos leidimą atlikti žmonėms skirto vaistinio preparato klinikinius tyrimus, esminių pataisų ir deklaracijos apie klinikinio tyrimo pabaigą pateikimo (CT-1). [2010] OL C82/1.

13. Europos Tarybos konvencija dèl žmogaus teisių ir orumo apsaugos biologijos ir medicinos taikymo srityje (Žmogaus teisių ir biomedicinos konvencija). Valstybès žinios. 2002, Nr. 97-4258.

14. Henderson, G. E., et al. Clinical Trials and Medical Care: Defining the Therapeutic Misconception. PLoS Medicine. 2007, 4: 1735-1738.

15. Hickman, N.; Prochaska, J.; Dunn, L. Screening for Understandingo of Research in the Inpatient Psychiatry Setting. Journal Of Empirical Research On Human Research Ethics. 2011, 6(3): 65-72.

16. Huthwaite, S. J., et al. Declining Medical Decision-Making Capacity in Mild AD: A TwoYear Longitudinal Study. Behavioral Sciences and the Law. 2006, 24: 453-463.

17. Iltis, A. Who Is A Patient and Why Does It Matter? American Journal Of Bioethics. 2011, 11(5): 62-64.

18. Informacija apie klinikinius tyrimus Lietuvoje 2012 metais. Valstybiné vaistų kontrolès tarnyba prie Lietuvos Respublikos sveikatos apsaugos ministerijos [interaktyvus]. Vilnius, 2012 [žiūrèta 2013-04-18]. <http://www.vvkt.lt/Metines-suvestines>.

19. Jeste, D. V., et al. A New Brief Instrument for Assessing Decisional Capacity for Clinical Research. Arch Gen Psychiatry. 2007, 64(8): 966-974.

20. Juškevičius, J. Kai kurie nepilnamečių ịtraukimo ị klinikinius vaistinių preparatų tyrimus teisiniai aspektai. Sveikatos mokslai. 2009, 6(66): 27-34. 
21. Knoepffler, N. Research: ethical norms for medical research on humans. Bundesgesundheitsblatt, Gesundheitsforschung, Gesundheitsschutz [interaktyvus]. 2008 [žiūrèta 2013-04-11]. <http://www.ncbi.nlm.nih.gov/pubmed/18787866>.

22. Lantz, M. S. The MacCAT-T for Evaluation of Decision-Making Capacity. Clinical Geriatrics. 2006, 14 (2): 15-18.

23. Lidz, Ch. W. The Therapeutic Misconception and Our Models of Competency and Informed Consent. Behavioral Sciences and the Law. 2006, 24: 535-546.

24. Lietuvos Respublikos biomedicininių tyrimų etikos įstatymas. Valstybės žinios. 2000, Nr. 44-1247.

25. Lietuvos Respublikos civilinio kodekso patvirtinimo, įsigaliojimo ir igyvendinimo itstatymas. Civilinis kodeksas. Valstybès žinios. 2000, Nr. 74-2262.

26. Lietuvos Respublikos farmacijos įstatymas. Valstybés žinios. 2006, Nr. 78-3056. 4 straipsnio 11 dalis.

27. Lietuvos Respublikos psichikos sveikatos priežiūros įstatymas. Valstybės žinios. 1995, Nr. 53-1290.

28. Lietuvos Respublikos sveikatos apsaugos ministro 1998 m. birželio 12 d. ịsakymu Nr. 320 patvirtintos Geros klinikinès praktikos taisyklès. Valstybès žinios. 1998, Nr. 57-1608.

29. Merton, V. The Exclusion of Pregnant, Pregnable, and Once-Pregnable People (a.k.a. Women) from Biomedical Research. American Journal Of Law \& Medicine.1993, 19(4): 369.

30. Miracle, V. Vulnerable Populations in Research. Dimensions Of Critical Care Nursing. 2010, 29(5): 242-245.

31. Moser, D., et al. Informed consent in medication-free schizophrenia research. American Journal of Psychiatry. 2005, 162: 1209-1211.

32. Nordentoft, H.; Kappel, N. Vulnerable participants in health research: methodological and ethical challenges. Journal Of Social Work Practice. 2011, 25(3): 365-376.

33. Osborn, D. P.; Fulford, K. W. Psychiatric research: what ethical concerns do LRECs encounter? J Med Ethics. 2003, 29: 55-56.

34. Palmer, B. W., et al. Correlates of Treatment-Related Decision-Making Capacity among Middle-Aged and Older Patients with Schizophrenia. Archives of General Psychiatry. 2004, 61: 230-236.

35. Palmer, B. W. Informed Consent for Schizophrenia Research: What is an Investigator (or IRB) to Do? Behavioral Sciences and the Law. 2006, 24: 447-452.

36. Paraiškos leidimui atlikti žmonèms skirtų vaistinių preparatų klinikinị tyrimą gauti, pranešimo apie esmines pataisas ir tyrimo pabaigos deklaracijos pateikimo tvarkos aprašas, patvirtintas Valstybinès vaistų kontrolès tarnybos prie Lietuvos Respublikos sveikatos apsaugos ministerijos viršininko 2006 m. liepos 14 d. įsakymu Nr. 1A-396. Valstybès žinios. 2006, Nr. 81-3241.

37. Pažyma dèl Seimo kontrolieriaus iniciatyva pradèto tyrimo prieš Valstybinę vaistų kontrolès tarnybą prie Lietuvos Respublikos sveikatos apsaugos ministerijos. Seimo kontrolierių įstaiga [interaktyvus]. Vilnius, 2013, Nr. 4D-2012/1-1418 [žiūrèta 2013-04-18]. $<$ http://www.lrski.lt/index_neig.php?p=0\&n=62\&l=lt\&search=0\&gr=\&pazyma=7021>.

38. Pritarimo atlikti klinikinị vaistinio preparato tyrimą liudijimų ir leidimų atlikti klinikinị vaistinio preparato tyrimą išdavimo, tyrimų atlikimo ir kontrolès tvarkos aprašas, patvirtintas Lietuvos Respublikos sveikatos apsaugos ministro $2006 \mathrm{~m}$. gegužès 31 d. įsakymu Nr. V-435, su pakeitimais. Valstybės žinios. 2006, Nr. 62-2292; 2010, Nr. 108-5566; 2011, Nr. 33-1569; 2011, Nr. 96-4524. 
39. Research Involving Individuals with Questionable Capacity to Consent: Points to Consider. U.S. Department of Health and Human Services [interaktyvus]. Bethesda, 2009 [žiūrèta 2013-06-30]. <http://grants1.nih.gov/grants/policy/questionablecapacity.htm>.

40. Robert, M. Veatch. Indiference of subjects: an alternative to equipoise in randomized clinical trials. Social Philosophy and Policy. 2002, 19: 295-323.

41. Saks, E. R.; Dunn, L. B.; Marshall, B. J.; Nayak, G. V.; Golsan, S.; Jeste, D. V. The California Scale of Appreciation: A New Instrument to Measure the Appreciation Component of Capacity to Consent to Research. American Journal of Geriatric Psychiatry. 2002, 10: 166-174.

42. Saks, E. R.; Jeste, D. V.; Capacity to Consent to or Refuse Treatment and/or Research: Theoretical Considerations. Behavioral Sciences and the Law. 2006, 24: 411-429.

43. Serretti, A.; Artioli, P. Ethical problems in pharmacogenetic studies of psychiatric disorders. The Pharmacogenomics Journal. 2006, 6: 1-7.

44. Stakišaitis, D., et al. Gera klinikinè praktika. Metodinès rekomendacijos tyrèjui. Vilnius: BSPB spaustuvè, 2005, p. 38-40.

45. Stakišaitis, D. Vaikų gydymo vaistais teisinio reglamentavimo aspektai. Jurisprudencija. 2008, 12(114): 36-43.

46. The PLoS Medicine Editors. Drug Development for Maternal Health Cannot Be Left to the Whims of the Market [interaktyvus] PLoS Med. 2008, 5(6): e140 [žiūrèta 2013-04-11]. $<$ http://www.plosmedicine.org/article/metrics/info\%3Adoi\%2F10.1371\%2Fjournal.pme d.0050140;jsessionid=FC58B269178859B36DD2CB536A1DF8DD $>$.

47. Zamarytė-Sakavičienė, K. Asmens sutikimo dalyvauti pediatriniame klinikiniame vaistinio preparato tyrime teisiniai aspektai. Socialiniu mokslų studijos. 2013, 5(1): 275-290.

\title{
Problematic Aspects of Legal Regulation of Vulnerable Subjects Participation in Clinical Trials of Medicinal Products
}

\author{
Kristina Zamarytè-Sakavičienè \\ Mykolas Romeris University, Lithuania
}

\section{Summary}

EU and national legal acts regulate authorization, conduction and control of clinical trials of medicinal products (CTMP). The purpose of legal norms regulating the CTMP is to ensure that data generated in these trials is of a good quality and that rights and well-being of trial participants are protected. Individuals, whose consent to participate in a clinical trial may be unduly influenced by the external circumstances, are regarded as vulnerable subjects.

This article analyses international, EU and Lithuanian legal acts, judicial practice and the doctrine of law in order to assess whether Lithuanian regulations of vulnerable subjects participation in the CTMP and the procedure of informed consent in psychiatric clinical trials provide sufficient protection of rights and interests of trial subjects and does not place unfounded obstacles to the conduction of the CTMP. Problematic aspects of the analyzed regulation are emphasized and possible solutions are given in the article.

The analysis leads to a few main conclusions. The lists of vulnerable populations provided in Law on Ethics of Biomedical Research of the Republic of Lithuania, Good clinical practice and Clinical trial Application Form endorsed at EU and national levels disagree. It would be purposeful to include pregnant, nursing women and women of child bearing potential into 
the vulnerable subjects list provided in Law on Ethics of Biomedical Research. In comparison to other countries and international documents, Lithuanian legal regulation establishes strict rules of protection of these subjects. According to Law on Ethics of Biomedical Research, clinical trials involving vulnerable subjects shall be permitted only where: 1) such biomedical research may be undertaken only on vulnerable subjects; 2) the results of the biomedical research may be of direct and real benefit to the health of these subjects; 3) the biomedical research will not pose a risk to the health or life of the subject. Law on Ethics of Biomedical Research should be changed to allow in exceptional cases to conduct nontherapeutic CTMP with vulnerable subjects and to clarify the acceptable level of risk to the health of the vulnerable subject in biomedical research. Complex regulation of the informed consent procedure in psychiatric research also has to be improved as it possesses difficulties not only for the conduction, but also for the control of the CTMP, and does not provide sufficient protection of psychiatric patients.

Keywords: clinical trial, biomedical research, medicinal product, vulnerable subject, psychiatric patient.

Kristina Zamarytė-Sakavičienè, Mykolas Romeris University, Faculty of Law, Department of Philosophy of Law and Legal History, Doctoral Student, Lecturer. Research interests: regulations of development of medicinal products.

Kristina Zamarytė-Sakavičienė, Mykolo Romerio universiteto Teisès fakulteto Teisès filosofijos ir istorijos katedros doktorantè, lektorè. Mokslinių tyrimų kryptis: vaistinių preparatų kūrimo teisinis reguliavimas. 